\title{
General Opinions about the Adoption of IAS/IFRS in Romania
}

\author{
Dragos Andrei Stoica ${ }^{1}$
}

Abstract

LAS /IFRS represent a set of global accounting standards that have gained a tremendous influence over national standards, regulations and organisations all across the globe. Romania's argument for being an interesting research case is given mainly by its longer experience with the standards over other countries in the region. Through this study, my aim is to highlight the arguments in favour of LAS/IFRS over the national GAAP by conducting a survey, addressed to the employees of the biggest 7 accounting firms in Romania.

Keywords: LAS/IFRS, actor, advantage, innovation

JEL Classification: A11, M41

DOI: $10.24818 / \mathrm{REJ} / 2021 / 82 / 11$

\section{Introduction}

With the passage of the new millennium, the mechanism of globalization has reached an unprecedented level of development (Godfrey and Chalmers, 2007). Technological progress and the accelerated development of information transmission systems have significantly contributed to the radical change in the organization and development of companies.

Accounting is a social practice embedded in a context that shapes and interacts with it, a context of significant pressures, threats and opportunities. Globalization shapes the accounting form, governance and its use worldwide (Gallhofer and Haslam, 2006).

International Financial Reporting Standards (IFRS) are a set of general principles used in preparing the financial statements, with the aim of achieving greater consistency of results, increasing the level of transparency and, at the same time, ensuring the comparability of information (IASB). , 2010). The standards are developed by the IASB and are the guide for companies that use them to conduct and report on business transactions. IASs $(1973$ - 2001) were issued by the International Accounting Standards Committee (IASC).

1 Bucharest University of Economic Studies, Romania, e-mail: dragos.stoica@ase.ro Year XXIV no. 82

December 2021 
The scope at the international level is to create a unitary set of reporting standards that can offer comparability, transparency and reliability not just inside the borders of a country, but at a global level. Thus, the mission of IAS/IFRS is quite clear: reduce the differences between national GAAP and IAS/IFRS. Since their introduction there are more than 100 countries that have adopted or pledged to adopt to IAS/IFRS.

The main objective of the standards is to provide useful information to investors, creditors and other stakeholders, in order to implement the best decisions (regarding the allocation of resources).

\section{Review of the scientific literature}

This study will be conducted from the perspective of a network of actors regarding the implementation of IFRS in Romania. Thus, we can assume that the action, in this case, translates to mediation, binding or modelling of organizational practices.

The actor network theory (ANT) is a constructivist approach in that it avoids essentialist explanations (the view that objects have a set of attributes necessary for their identity (Cartwright, 1968) of innovations (e.g., ANT explains a theory by understanding combinations). and the interactions of the elements that make it successful, rather than claiming what is true and what is false.) At the same time, it is not a cohesive theory in itself (Carroll et al., 2012). a strategy that helps people to be more sensitive to unexplored terms and hypotheses (Law, 1992) The material-semiotic approach is one of the main distinguishing points that separates ANT from other theories and sociological networks (Carroll, 2014).

Romania is a developing country and there is a strong accord that it faces various problems in applying IFRS (Feleaga and Feleaga, 2016). After the fall of the communist regime, the social and financial systems went through a series of changes. As a direct result, the accounting profession has experienced significant modifications (the regulatory system, the supervisory system, the reporting system etc.).Thus, the orientation of Romanian accounting towards international standards began in the late 1990s, due to several factors. The Romanian system has made major efforts to adapt to these new regulations given the very distinct cultural, economic, financial, social and business environment. An issue arose due to the close connection of standards with the Anglo-Saxon thinking environment. This situation has created difficulties for the Romanian accounting profession (practitioners, trainers, auditors, CFOs) in understanding and correctly applying international standards.

Year XXIV no. 82

December 2021 
Another chapter of the continuous process of implementing and fully adopting IAS/IFRS has started in 2012, when the financial reporting of listed entities on a regulated market had to be done in accordance with the Standards (Albu et al., 2011; Albu et al. ., 2020). One of the qualities of this change was to better promote transparency and the comparability of the financial statements, helping the main actors (investors, creditors, the state etc.) to have a higher degree of confidence in the presented information (Ionașcu et al., 2014; Albu et al., 2011; Feleagă and Feleagă, 2016; Albu et al., 2020).

Through these changes, the Romanian accounting profession has gradually become familiar with the concepts of IFRS. However, moving to international standards has not been easy. Several actors, such as representatives of international organizations, parent companies, the state and professionals, have played a significant role in embracing IFRS (Albu and Albu, 2012; Albu et al., 2011; Albu et al., 2020).

Many authors (Ionașcu et al., 2014; Albu et al., 2011; Feleagă and Feleagă, 2016; Albu et al., 2020) find that the degree of compliance is relatively low in our country, even though there are noteworthy differences between companies.

\section{Research methodology}

In order to answer the research question, what are the advantages of the adoption of international IAS / IFRS standards in Romania? I have prepared and disseminated a questionnaire among the 7 most important companies in the field of accounting and auditing, among those that take care of their activity in Romania. The questionnaire was disseminated to the employees of the accounting, auditing and financial departments within these entities, between December 2019 and January 2020. The response rate was considered relevant (Nazari et al., 2011). The query was sent to the actors via e-mail.

The structure of the questionnaire was twofold: Section 1 - Demographic data of the respondents; Section 2 - Opinions on the adoption and implementation of IAS / IFRS in Romania. The questions evaluated the interviewees responses using the Likert scale (where 1 - not at all - 5 - to a large extent). The interviewed actors had to respond to 32 statements proposed by the author, out of which 10 will be analysed in this paper.

Year XXIV no. 82

December 2021 


\section{Results and discussion}

The demographic results of the study indicates that almost $70 \%$ of the 111 respondents are female, which confirms the usual trend of the high number of female representatives in the field of accounting and economics. Another important aspect that we can observe is the age of the respondents. Thus, over $88 \%$ of them are between 22 and 35 years old, the next category in terms of size being that of respondents over the age of 35 (9.01\%). Regarding the level of studies of the participants in this study, it can be seen that the majority $(66.67 \%)$ graduated the master's degree, $19.82 \%$ graduated only undergraduate studies, and $13.51 \%$ have a doctorate in the field.

The research aimed to create a more complex picture not only on the aspects regarding the implementation and adoption of IFRS in Romania, but also on the information regarding the respondents. Thus, we know that there is a balanced distribution of the workplace of respondents $(28.83 \%$ - work in companies within the BIG4 group; $32.43 \%$ - work in companies with domestic capital; 36.94\% work in subsidiaries of multinational companies). Regarding the work experience of the respondents, it is observed that the majority $(50.45 \%)$ have an experience between 1 and 3 years, $27.03 \%$ have an experience of up to one year, and the rest have an experience of over 3 years.

Another important aspect that had to be questioned in the study was the level of familiarity of the respondents with the IAS / IFRS Standards. To evaluate the answers we chose to use the Likert scale (1-5, where 1 - not at all and 5 - largely). Only $6.31 \%$ answered that they have a level marked with 2 on the Likert scale, which gives a very high credibility and relevance of the answers in this study.

Table 1. General opinions for IAS/IFRS

\begin{tabular}{|l|l|l|l|}
\hline \multicolumn{1}{|c|}{ Items } & Average & Median & \multicolumn{1}{c|}{$\begin{array}{c}\text { Standard } \\
\text { deviation }\end{array}$} \\
\hline $\begin{array}{l}\text { The implementation of IFRS in Romania was done in a } \\
\text { manner comparable to the same process in other European } \\
\text { Union countries }\end{array}$ & 3.68 & 4 & 0.92 \\
\hline
\end{tabular}

Source: Author's own projection

Respondents' agreement on the statement "the implementation of IFRS in Romania was done in a manner comparable to the same process in other European Union countries" is slightly above average, and in the answers given to the questions below we will highlight the issues that generate differences between the implementation of IAS / IFRS in Romania compared to other countries. 
H1. The reliability of the information presented in the financial statements prepared in accordance with IAS / IFRS may be influenced by the A1-A4 advantage factors presented in Table 2.11. Presentation of advantage factors.

Table 2. Coding of the advantage factors

\begin{tabular}{|l|l|}
\hline Abbreviation & \multicolumn{1}{|c|}{ Description of indicators } \\
\hline F_A1 & $\begin{array}{l}\text { Advantage - IFRSs provide market users with more transparency } \\
\text { market }\end{array}$ \\
\hline F_A2 & $\begin{array}{l}\text { Advantage factor - IFRS contributes to the increase in demand for shares from } \\
\text { foreign investors }\end{array}$ \\
\hline F_A3 & $\begin{array}{l}\text { Advantage - IFRS limits managers' ability to manipulate financial statements and } \\
\text { mislead investors }\end{array}$ \\
\hline F_A4 & $\begin{array}{l}\text { Advantage factor - IFRS provides users with more reliable information on the } \\
\text { market }\end{array}$ \\
\hline F_A6 & $\begin{array}{l}\text { Advantage - IFRS provides companies with more reliable information (compared } \\
\text { to national standards) }\end{array}$ \\
\hline F_A7 & $\begin{array}{l}\text { Advantage factor - IFRS provides companies with information closer to the } \\
\text { economic reality compared to national standards that can encourage companies to } \\
\text { prepare financial statements with the main objective of the tax result }\end{array}$ \\
\hline F_A8 & $\begin{array}{l}\text { Advantage - IFRS facilitates a higher level of comparability between firms and } \\
\text { their competitors and therefore can better assess their market position }\end{array}$ \\
\hline Sorke &
\end{tabular}

Source: Author's own projection

Starting from the H1 hypothesis regarding the testing of the level of influence of the advantage factors - IFRS provides users with information on the market with a higher level of transparency, IFRS contributes to streamlining the Romanian capital market, IFRS contributes to increasing the demand for shares from foreign investors, IFRS limits the ability of managers to manipulate financial statements and mislead investors - on the reliability of accounting information obtained by applying the Standards we get the following results.

Using an $\alpha=0.05$, we have a degree of significance $F<\alpha$. This confirms the proposed model. At the same time, the multiple correlation coefficient (0.82) shows a strong link between the dependent variable Y (IFRS provides users with more reliable information) and the independent variables stated in the previous paragraph. Another argument in support of the proposed model is the coefficient of determination R2 (67\%), which shows that the variation of the independent variables (x) largely explains the variation of the dependent variable $(\mathrm{Y})$.

Year XXIV no. 82

December 2021 
Table 3. Estimated results of the H1 model

\begin{tabular}{|c|c|}
\hline \multirow{2}{*}{ F_A1 } & Reg_1 \\
\cline { 2 - 3 } & $0.50^{* * *}$ \\
\hline \multirow{2}{*}{ F_A2 } & $(2.69)$ \\
\cline { 2 - 3 } & $0.18^{* *}$ \\
\hline \multirow{2}{*}{ F_A3 } & $(2.54)$ \\
\cline { 2 - 3 } & 0.06 \\
\hline \multirow{2}{*}{ F_A4 } & $(0.81)$ \\
\cline { 2 - 3 } & $0.10^{* * *}$ \\
\hline R ${ }^{2}$ & $(1.87)$ \\
\hline \multirow{2}{*}{$\begin{array}{l}\text { Note: * **, *** symbols represent 10\%, 5\% and 1\% significance levels } \\
\text { Source: Author's own projection }\end{array}$}
\end{tabular}

We can see from Table 3. The estimated results of the $\mathrm{H} 1$ model, the fact that F_A1 has a strong positive impact in ensuring the reliability of financial information, the T-statistical result can be found in parentheses. Factors whose correlation exceeded a level of 0.3 were not analyzed. At the same time, a strong positive influence can be observed in the case of F_A4.

Thus, survey participants believe that transparency and limiting managers' ability to influence financial statements are two of the most important benefits of the H1 hypothesis. These results are to be expected, as they are also found in other specialized studies (Albu et al., 2011; Albu et al., 2012; Ionașcu et al., 2011, Ionașcu et al., 2018). Within the same regression, we can observe that there is no significant correlation relevant for H1 and F_A3 (demand for shares from foreign investors).

\section{Conclusions}

ANT offers us a rich constellation of actors, be they people (stakeholders, shareholders, board members, managers, heads of bodies, institutions and entities, etc.), or non-people (capital market, bodies, organizations, political system, state, etc.), which based on the analysis performed, we can observe the important role they've played both as individuals and as a network in the adoption and implementation of the Standards in Romania. 
Based on demographic information, we can draw the following conclusions for Questionnaire 1:

- Over $69 \%$ of respondents were female;

- Over $88 \%$ of respondents are over 22 years old;

- $2 / 3$ of them studied for a master's degree;

- The distribution of respondents according to the type of company in which they work is numerically balanced for the proposed categories;

- Approximately $97 \%$ of respondents have at least one year of work experience;

- $73 \%$ of respondents have direct experience working with standards of at least one year;

- $71 \%$ of respondents stated that they were at least 4 familiar with the Likert scale with the standards.

Based on the results we can state that the information generated by the application of standards enjoys a high degree of reliability.

From the analysis we can confirm the following model: The reliability of the information presented in the financial statements prepared in accordance with IAS / IFRS is influenced by the following factors: IFRS provides market users with information with a higher level of transparency***; IFRS contributes to the efficiency of the capital market**; IFRS limits managers' ability to manipulate financial statements and mislead investors*** $(\mathrm{R} 2=67.46 \%)$;

Therefore, I can conclude that based on the results obtained, the importance and necessity of the continuous task of implementing the Standards is very high and very clear, and in order to ensure full adoption, implementation and convergence we need, as a state, a more favourable legislation for the Standards, to support higher level of professional education and a clearer differentiation between accounting and tax results.

\section{References}

Albu, N., Albu, C. N., Bunea, Ş., Calu, D. A., \& Girbina, M. M. (2011). A story about IAS/IFRS implementation in Romania. Journal of Accounting in Emerging Economies.

Albu, N., \& Albu, C. N. (2012). International Financial Reporting Standards in an emerging economy: lessons from Romania. Australian accounting review, 22(4), 341-352.

Albu, N., Albu, C. N., Dumitru, M., \& Dumitru, V. F. (2013). Plurality or convergence in sustainability reporting standards? Amfiteatru Economic Journal, 15(Special No. 7), 729-742. 
Albu, C. N., Albu, N., \& Alexander, D. (2014). When global accounting standards meet the local context-Insights from an emerging economy. Critical Perspectives on Accounting, 25(6), 489-510.

Albu, N., Albu, C. N., \& Gray, S. J. (2020, July). Institutional factors and the impact of international financial reporting standards: the Central and Eastern European experience. In Accounting Forum (Vol. 44, No. 3, pp. 184-214). Routledge.

Carroll, N., Richardson, I., \& Whelan, E. (2012). Service science: An actornetwork theory approach. International Journal of Actor-Network Theory and Technological Innovation (IJANTTI), 4(3), 51-69.

Cartwright, R. L. (1968). Some remarks on essentialism. The Journal of Philosophy, 65(20), 615-626.

Feleagă, L., \& Feleagă, N. (2016). Romania. Shifting to IFRS: The Case of Romania. In IFRS in a Global World (pp. 393-404). Springer, Cham.

Gallhofer, S., \& Haslam, J. (2006). The accounting-globalisation interrelation: An overview with some reflections on the neglected dimension of emancipatory potentiality. Critical Perspectives on Accounting, 17(7), 903-934.

Godfrey, J. M., \& Chalmers, K. (Eds.). (2007). Globalisation of accounting standards. Edward Elgar Publishing.

Ionascu, M., Ionascu, I., Sacarin, M., \& Minu, M. (2014). IFRS adoption in developing countries: the case of Romania. Accounting and Management Information Systems, 13(2), 311.

Law, J. (1992). Notes on the theory of the actor-network: Ordering, strategy, and heterogeneity. Systems practice, 5(4), 379-393.

Nazari, J. A., Herremans, I. M., Isaac, R. G., Manassian, A., \& Kline, T. J. (2011). Organizational culture, climate and IC: an interaction analysis. Journal of intellectual capital. 